\title{
Railway Network Development in Inter-war Romania: Economic and Strategic Motives
}

\author{
Turnock, D.*
}

Abstract The railway geography of the Pannonian zone was substantially reconstructed after the First World War as a result of the demise of the Habsburg Empire and the need for unity within the new states of the region. While some main lines were effectively destroyed like the direct link between Szeged and Timisoara (which is only now being revived in the context of European support for cross-border cooperation), many new connections were proposed across the former imperial frontiers. This study deals with Romania where former Carpathian frontier needed radical attention. But as achievements of the period 1919-49 are examined it is evident that the ambitious proposals of the expansionists were compromised by need for careful prioritisation given the limited finance and the engineering challenges; also the need to reconcile economic and strategic interests and provide for qualitative improvements throughout the system as a whole as well as new construction.

Key words soils, degradation, melioration, fertility, Banat, Romania
This is a study in historical geography which considers one aspect of a 1 major problem facing Romania (and all the newly-constituted or greatly-enlarged states of East Central Europe) after the First World War in that the inherited infrastructure was not only worn out and heavily damaged but also needed thorough integration on account of the new provinces acquired from the defeated powers - in Romania's case: Banat, Crisana, Maramures and Transylvania from Hungary, Bessarabia from Russia and Bucovina from Austria. The railway system of Romania presented this problem in an extreme form since the country was more than doubled in size and there was the additional problem of a difference of gauge in Bessarabia. The focus is placed on the expansion of the network, with a review of each of the projects selected, following the author's previous works (Turnock, 1978; 1987). Both economic and strategic motives were important although the balance between them shifted during the period. The study extends to 1949 so as to deal with some projects whose completion was delayed until just after the Second World War and cover all the years prior to the launch of the first communist Five Year Plan. But progress was restrained by other

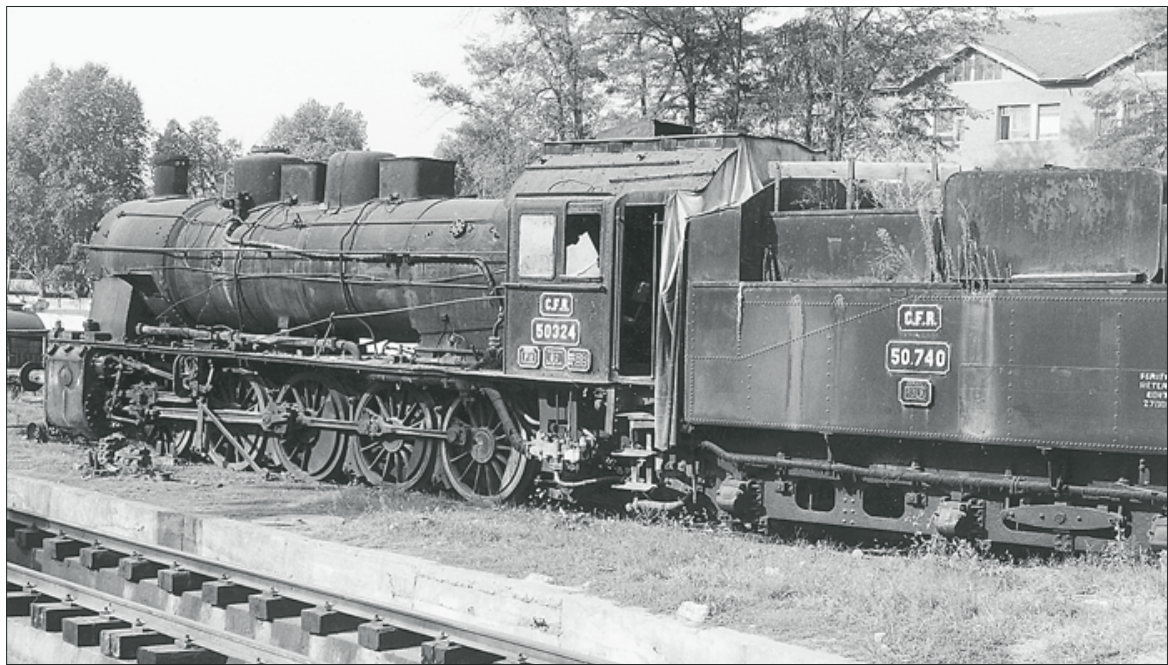

Plate 1. A heavy freight locomotive of the type built by Malaxa at Bucharest from 1928, photographed at Ramnicu Valcea economic problems. Serious war damage gave way massive reconstruction problems after the oilfields had been recklessly exploited during the German occupation. There was also a need for financial reconstruction complicated by the loss of gold reserves in Russia and the erosion of Reichsbank credits in Germany through inflation, not to mention the fiscal burden of Romania's allocation of the Austro-Hungarian debt.

\section{Priorities Within the Railway Industry}

Even within the railway industry there was much competition for funding. The challenge over standardisation of axle weights and maximum speeds is very evident when it is considered that seven types of rail were in use across Romania before the war compared with 48 after. An axle weight of $18 \mathrm{t}$ was the norm in 1919 but 19t was acceptable by 1929; and there was particular acceleration in Bessarabia during 1918-32: from 30 to $80 \mathrm{~km} / \mathrm{h}$ maximum speed between Ungheni to Chisinau and $10-60 \mathrm{~km} /$ $\mathrm{h}$ between Ungheni, Balti and Sulita (reconstructed by 1928). But extensive renewal was also needed to cope with war damage including 154 railway bridges, the most important which was Saligny's bridge over the Danube between Fetesti and Cernavoda, reopened for access to Constanta in 1921 But with the bridge over the Milcov near Focsani unavailable until rebuilding was completed in 1923 all rail traffic to Moldavia from the south had to pass through Galati where the bridge at Barbosi attracted top priority and was restored relatively quickly in 1919. Severe winter weather could disrupt the network (as in 1933-4) but more serious was the risk of a sudden increase in temperature causing accelerated snow-melt and serious flooding; requiring reconstruction of Stramba bridge over
David Turnock, Geography Department, The University, Leicester LE1 7RH, United Kingdom 
the Jijia between Iasi and Ungheni during 1932-3; while river regulation, especially for the Bahlui and Barlad rivers, was called for to reduce the level of risk. Heavy wear and tear to Timis tunnel (Brasov-Predeal) arising through sulphurous smoke emitted by the passage of heavy trains hauled by up to four locomotives required a two-month closure for major repairs in 1933.

There was also modernisation work involving locomotives and rolling stock. Whereas all locomotives were purchased abroad before 1914 there was an almost exact 50:50 split between 1914 and 1927 (1,087 locomotives built in Romania; 1,077 abroad) and between 1927 and 1938 there were only 109 imported compared with 760 built within the country; thanks to capacities established at Resita in 1926 (where previously only narrow gauge locomotives had been built) and in Bucharest where Malaxa started to build heavy freight locomotives in 1928 (Plate 1). New locomotives, especially the Pacifics imported from Maffei in Germany paved the way for a 'rapid' train service inaugurated by the 'Ardeal' Express from Bucharest to Brasov in 1929 and followed up in 1931 by the 'Tomis' to Constanta and the 'Unirea' to Iasi

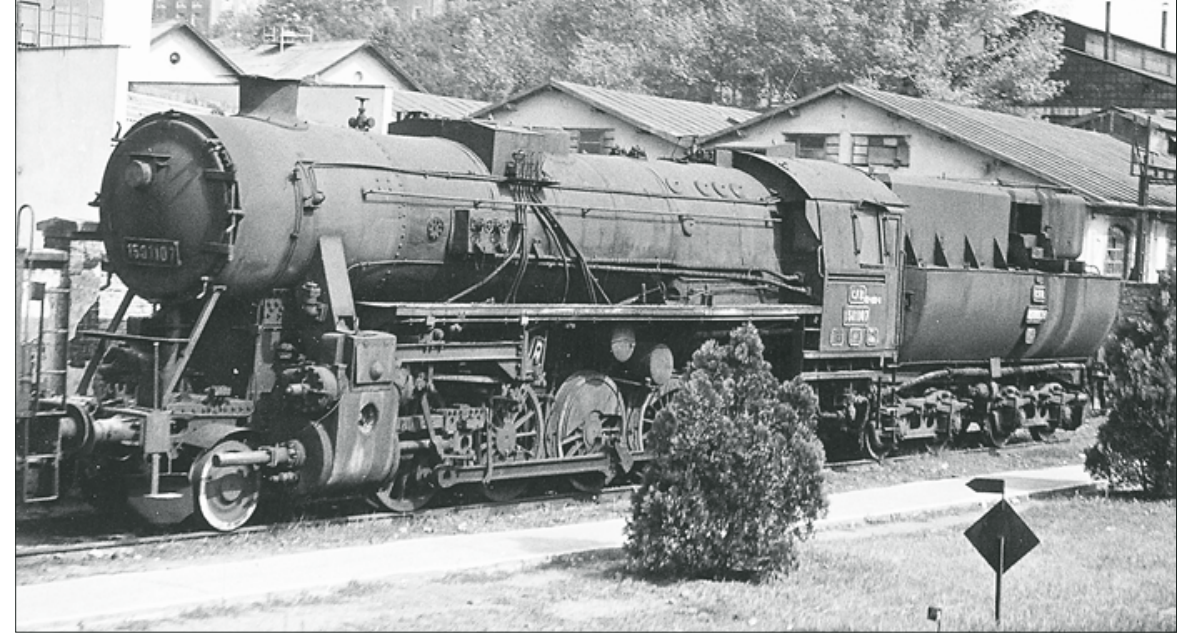

Plate 2. A former German war locomotive used for mixed traffic until the 1980s, photographed at Turnu Severin

bridging was in place as far as Roman at the end of the war.

Much attention was given to stations and administration in Bucharest with a costly new central station abandoned in 1932 in favour of major extensions at Gara de Nord - including the transfer of railway rolling stock repair shops to make way for a new administrative complex (1937-9) and other buildings - and new stations in

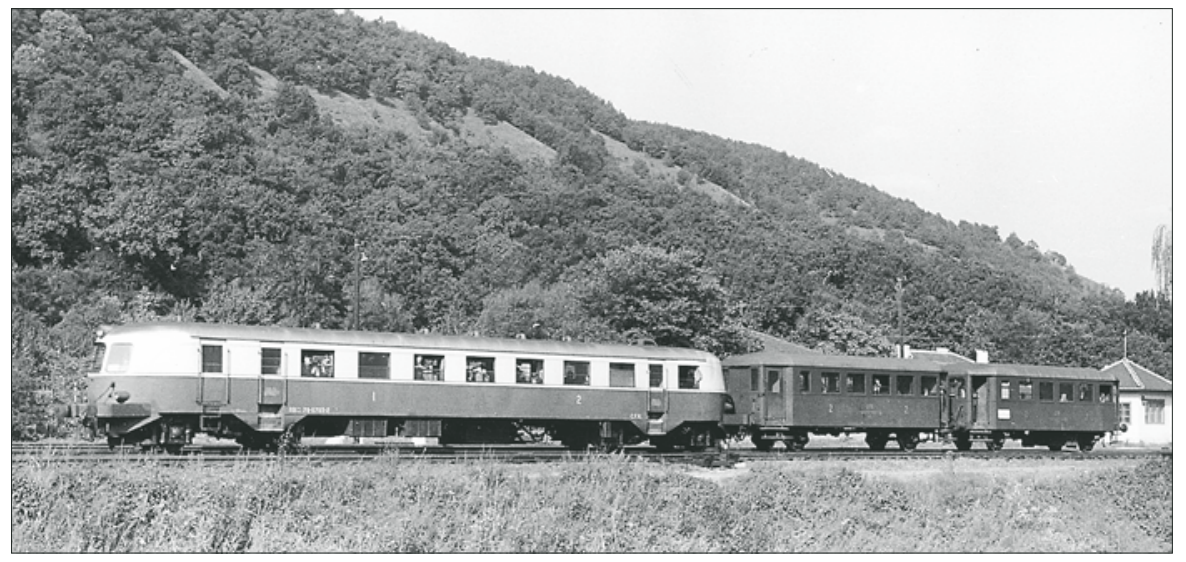

Plate 3. An express diesel railcar modelled on a Hungarian design photographed at Podul Olt and Chisinau. Steam traction continued to evolve through the 1930s and 1940s (Plate 2 ), but the improvement of inter-city services by fast steam-hauled trains was taken a stage further with express diesel railcars in the 1930s (Plate 3). The widening of main lines by laying a second track was limited in 1918 to Bucharest-Ploiesti-Campina, Ploiesti-Buzau and the short section from Iasi to Letcani where the Dorohoi and Pascani lines diverged. But widening was extended from Campina to Brasov (1939-41); Buzau to Adjud and Tecuci (1933-41); and a section in Transylvania from Copsa Mica to Teius and Apahida (1938-40) - although the latter was quickly removed on account of the new frontier with Hungary established in 1940. These improvements came quite late considering that the doubling of the track all the way to the Polish frontier was recommended in the Cottescu programme of 1927. In 1943 doubling started north of Adjud and most of trackbed and the suburbs at Obor (1932) and Baneasa (1939) (Plate 4). Electric signalling was one of the reasons calling the railway company to open its own power station at Grivita in 1937. Meanwhile, diesel shunting locomotives were also in production at the end of the 1930s, while diesel railcars helped limit costs on existing branch lines (Plate 5). And the growth of road transport (albeit with state railway company in a privileged position to operate buses and lorries - as was also the case with airlines and pipelines) limited the case for new local lines unless substantial freight movement(minerals or timber) was anticipated.

\section{The Electrification Debate}

Most controversy related to electrification which started on present Romanian territory in 1906 with petrol-electric power for the services from Arad to Ghioroc, Pancota and Radna in 1906 (switching to a static power station in 1912). In 1913 electrifica- tion for the heavily-used and steeply-graded Ploiesti-Predeal line was proposed by R.Baiulescu and I.S.Gheorghiu using hydropower from Dobresti and Gaina stations but was not included in the development plan of that year. In 1922 Gheorghiu saw the hydro potential of the Basca valley as a basis for electrification of the Prahova valley line: then single-track railway climbing to the Predeal summit $(1040 \mathrm{~m})$ with gradients of $2.0-2.5 \%$. After a favourable report by a Swiss expert in 1926 government approved electrification in principle in 1929 at a time when a foreign loan was linked with a Bucharest-Danube Canal that was a potential source of power. D.Serbanescu (1936) and others recommended additional electrification for lengthy routes incorporating new Carpathian routes such as Bumbesti-Livezeni, Curtea de Arges-Ramnicu Valcea, Harman-Nehoiasu and Ilva Mica-Vatra Dornei. Other visionaries proposed a national electricity grid with a roughly circular pattern following the main line railways, thereby linking a series

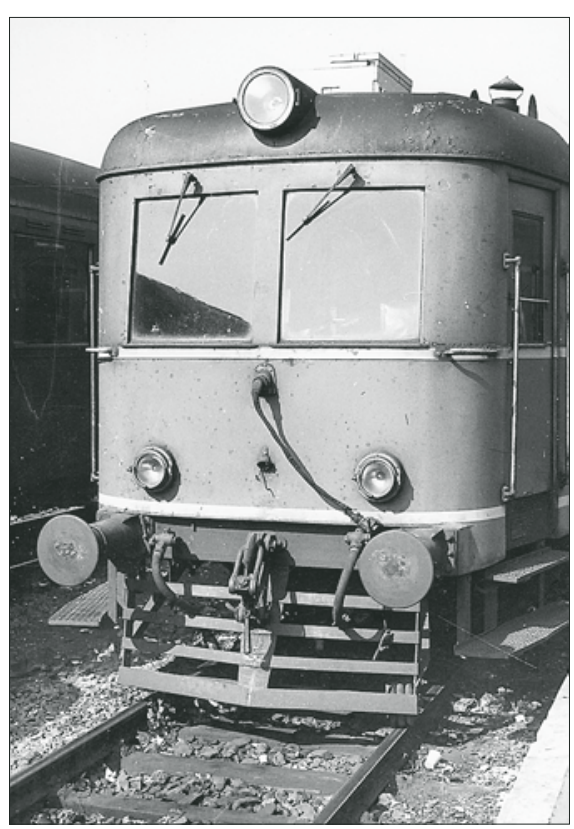

- Plate 4. A type of diesel railcar used for light branch-line traffic 


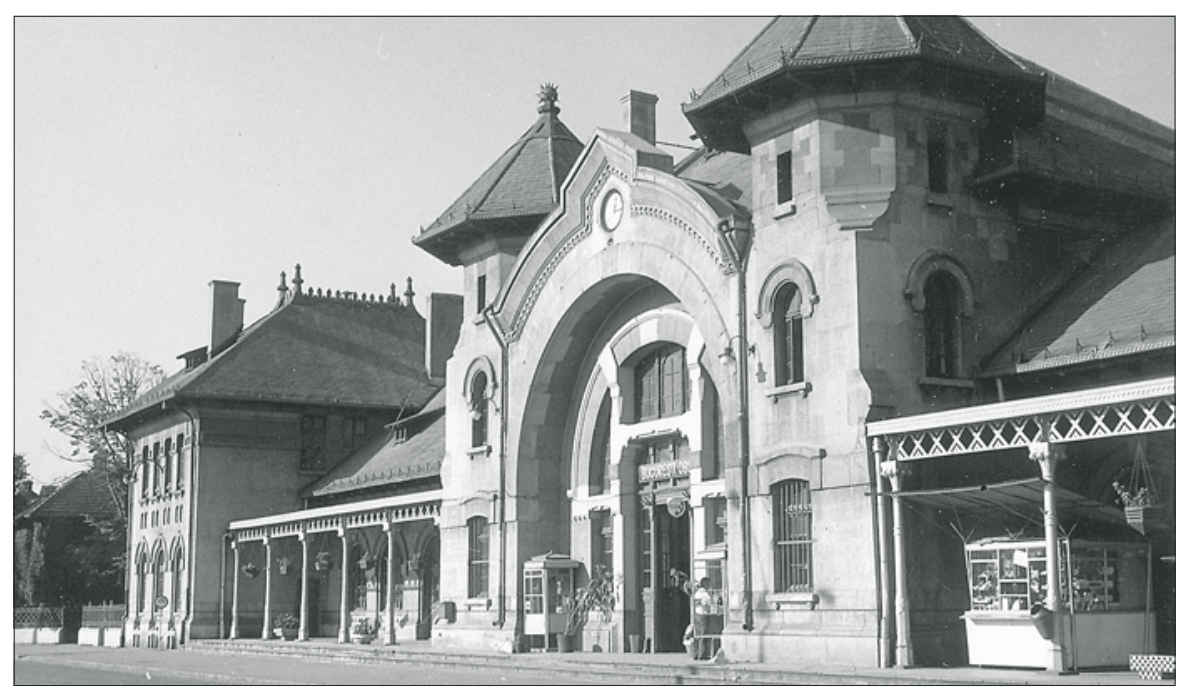

Plate 5. The new station of Bucharest Obor built in the 1930s

of hydropower stations and the main coal, gas and oil fields: in this way railway electrification could then take place on a more comprehensive basis. But feasibility studies in 1929-30 restricted electrification to Campina-Brasov, which was always seen as the top priority since it would obviate the need for relief lines. This project was subsequently examined by commissions during 1932-4 and government voted money in 1935 for 3000v conversion in liaison with German and Italian firms (though bids received in both 1931 and 1935 were considered too expensive).

By now the route over Predeal was saturated with traffic to the point where 21,500 wagons had to be diverted to more circuitous routes via Ghimes-Ciceu or the Olt Valley (though better planning reduced this level to 7.7 in 1938). But with opposition over the vulnerability of power stations to bombing and the disproportion ate spending on one project (through the cost of imported equipment given the limited development of the Romanian electrical engineering industry at the time) the project was postponed pending the widening of the line and testing of a 4,000hp Sulzer diesel-electric locomotive ordered in 1936 and delivered in 1938. Furthermore the decision was taken to extend the double track from Campina to Brasov in 1939 The expense of electrification was also countered by the improved fuel situation for locomotives as the coal resources of the former Habsburg territories became available. Between 1921 and 1941 increasing use was made of hard coal from the Jiu Valley (enhanced by washing facilities in 1929), lignite from a range of small mines developed before the war (with new briquetting facilities at Calnic near Resita and Comanesti) and certain grades of oil. Imports of coal ceased, as did use of the high-grade Anina coal, and consumption of wood was greatly reduced. Between 1937 and 1941 the total amount of fuel used (equivalent to $1.53 \mathrm{mln}$.t of Cardiff coal) involved $63.3 \%$ Jiu Valley coal; $16.1 \%$ lignite; $20.3 \%$ oil and only $0.3 \%$ timber. Comparative values for $1921-7$ were $51.9 \%, 15.5 \%$, 20.7\% and $10.4 \%$ respectively (imported coal then accounted for the remaining 1.6\%).

A political contest between the Liberal and National-Peasant parties, with the former sponsoring an industrial class on the basis of self-help 'prin noi insine' (including a deflationary strategy to revalue the national currency) while their opponents favoured foreign investment. The Liberals held sway initially and were favoured as the king's party until Ferdinand's death in 1927. The Liberals established a higher value for the leu in 1926 and 1927 on the strength of relatively good harvests but it could only be defended with difficulty. And although agriculture and exports were taxed to finance industrial growth, the inefficiency of much domestic industry caught the rural consumer in a price scissors between unrewarding prices for farm produce and rising relative costs for manufactures. Even oil prices were disappointing and increasing production during 1924-7 could not always keep pace. However there were ambitious railway proposals from N.I.Petculescu (1923) as well as R.Baiulescu and A.Cottescu and a programme evolved within the Ministry of Public Works \& Transport during the early 1920s and three mountain projects were launched in 1924. Resources allowed a substantial effort at this time, although certain key projects did not reach completion until a new government was in control and a $\$ 100 \mathrm{mln}$ foreign loan negotiated following monetary stabilisation. At this juncture (1929) G.Leverve, a French railway specialist, was invited to make a survey to help reorder priorities, based very largely on economic considerations. The depression undermined the new strategy and when recovery occurred there was a more difficult political climate and a royal dictatorship under Carol II as strategic issues came to the fore through a range of projects

\section{The Political Context for New Construction}

discussed by Tudoran (1934). A new start was heralded in 1937 with the creation of a new construction organisation for military projects ('Serviciul Lucrarilor Militare') which eventually evolved into the 'Centrala de Constructii Cai Ferate' prominent through the communist years. The unit took over work on the Bumbesti-Livezeni and Ilva Mica-Vatra Dornei projects as well as several others based at Babadag, Brad, Bucharest, Caransebes, Crasna, Eforie and Salva. Finally, the loss of North Transylvania in 1940 dictated a new set of priorities - concerned with the internal requirements of the state and the Axis advance in the Soviet Union - which were mostly taken through to completion by the end of the 1940s (Tudoran, 1941)

\section{The Projects: Completing Wartime Construction and Filling the Gaps}

The paper presents a total of 50 projects completed between 1921 and 1949 and makes use of a valuable engineering study (Iordanescu \& Georgescu, 1986) which is taken as the authority where minor discrepancies in dates arise. Each project had a serial number that can be found on Figure 1 . Some work can be seen as a contin uation of work started during the war. Although many wartime projects were simply abandoned like the narrow gauge lines from Husi to Bucovat in Bessarabia and Borsa to Iacobeni (which the Hungari ans dismantled before retreating), the Romanians completed the $45 \mathrm{~km}$ line (started in 1917) from Roman to Bacesti in 1921 (1) which linked with the Buhaiesti-Bacesti branch of 1915 and completed a crosslink between the two north-south axial lines through Moldavia. This became a priority when the Romanian government retreated to Iasi and most of the country fell under German occupation. In non-occupied territory the administration depended on the single-track railway 'ring' connecting Iasi, Barlad, Tecuci, Marasesti, Bacau, Roman and Pascani and because of single line working all traffic was required to move in a clockwise direction. The new link was seen as a way of easing pressure and was evidently seen as being useful in peacetime. The other project in this category was the line started by the Russians to connect Cetatea Alba with Zorleni near Barlad across Bessarabia. The outstanding work over the $112 \mathrm{~km}$ section between $\mathrm{Ba}$ sarabeasca and Zorleni was completed in 1923 (2) following the completion of a temporary wooden bridge over the Prut at Falciu (replaced by a metal structure in 1928). However the work started to cross the old frontier further north and connect Dangeni (on the Iasi-Dorohoi line) with Radauti-Prut and Lipcani was evidently too limited for completion to be an easy option. 


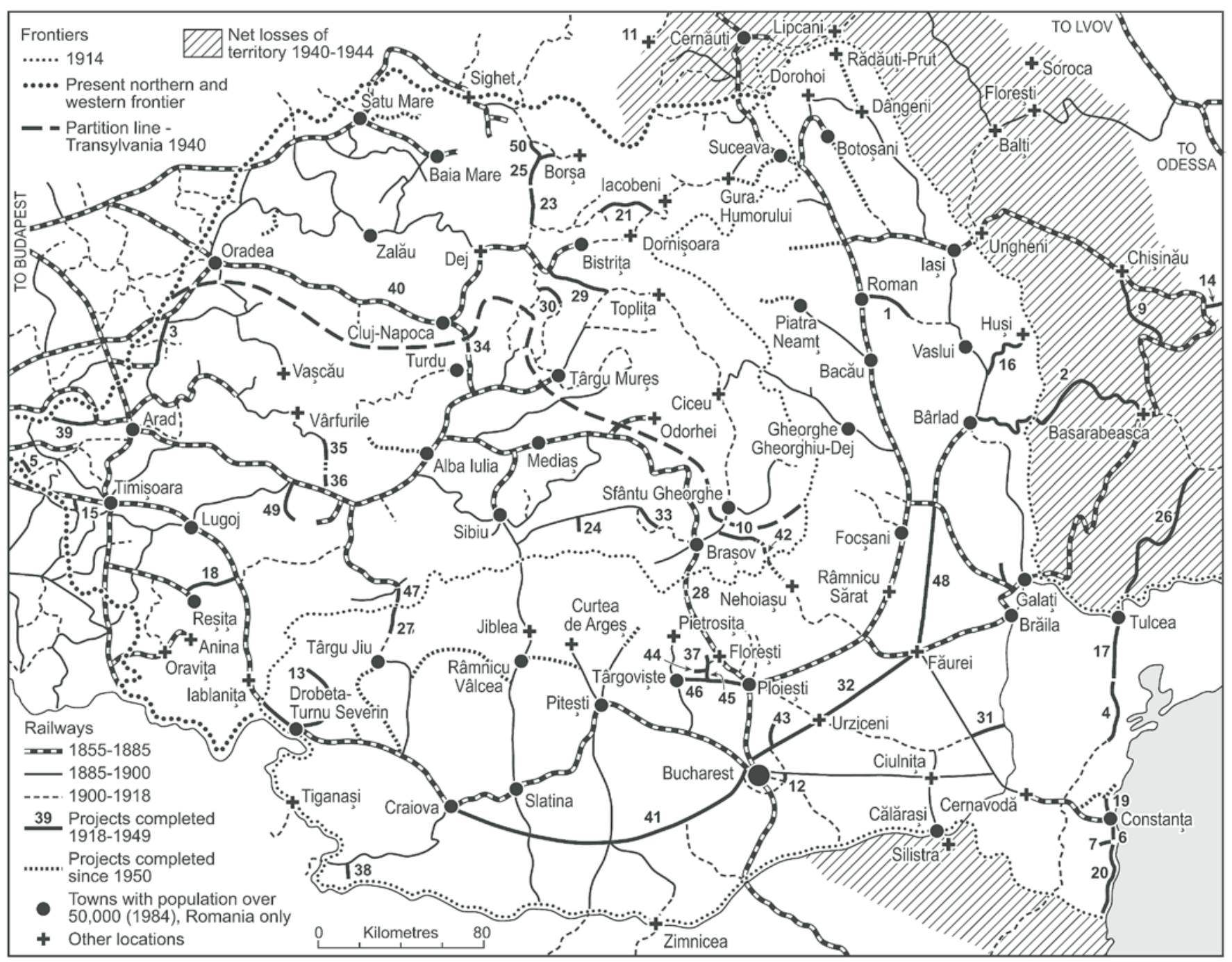

Figure 1. The Romanian railway system highlighting the projects completed during 1918-1949. Key to projects:

1. 1921 Roman-Bacesti (now Maresal Constantin Prezan) (45kms), 2. 1923 Zorleni-Basarabeasca (112kms), 3. 1924 Nadab-Salonta (35kms), 4.1925 Hamangia-Babadag (22kms), 5. 1927 Comlosu-Teremia (9kms), 6.1927 Constanta-Eforie (18kms), 7. 1928 Eforie-Techirghiol (2kms), 8. 1930 Schit-Zaleszczyki@(\#), 9. 1931 Revaca-Cainari (44kms), 10.1931 Harman-Intorsura Buzaului (31kms), 11.1931 Vijnita-Kuty (5kms), 12.1932 Bucharest Obor-Pantelimon (5kms), 13.1934 Apa Neagra-Turnu Severin ( $\left.{ }^{*} 40 \mathrm{kms}\right), 14.1935$ Tighina-Tiraspol (\#), 15.1937 Carpinis-Checea (7kms), 16.1937 Crasna-Husi (34kms), 17.1938 Babadag-Tulcea 1938 (39kms), 18.1938 Caransebes-Resita (34kms), 19.1938 Constanta-Mamaia 1938 (11kms), 20.1938 Eforie-Mangalia 1938 (26kms), 21.1938 Ilva Mica-Vatra Dornei (62kms), 22.1939?Larga-Kamjanec Podilskyi@ (*40kms), 23.1939 Salva-Telciu (15kms), 24.1939 Ucea-Victoria (10kms), 25.1940 Telciu-Moisei (*20kms), 26.1941 Arciz-Ismail ( $\left.{ }^{*} 65 \mathrm{kms}\right), 27.1941$ Bumbesti-Meri ( $(\mathrm{kms}), 28.1941$ Busteni/Posada (\#), 29.1941 Deda-Saratel (47kms), 30.1941 Iuda-Lechinta (16kms), 31.1942 Tandarei-Lunca (16kms), 32.1943 Bucharest-Faurei (138kms), 33.1943 Sercaia-Valea Homorod (16kms), 34.1944 Boj Deviation (3kms), 35.1944 Brad-Luncoiu (5kms), 36.1944 Deva-Stoeneasa (15kms), 37.1945 Filipestii de Padure-Mina Palanga (5kms), 38.1945 GolentiPoiana Mare (7kms), 39.1945 Pecica-Nadlac (31kms), 40.1945 Stana Tunnel (1km), 41.1947 Bucharest-Craiova (209kms), 42.1947 Intorsura Buzaului-Crasna ( $\left.{ }^{*} 20 \mathrm{kms}\right), 43.1948$ Caciulati-Snagov (16kms), 44.1948?Ditesti-Moreni/Mina Palanga (15kms), 45.1948?I.L.Caragiale-Ditesti (9kms), 46.1948 Ploiesti-Targoviste (52kms), 47.1948 Meri-Livezeni (20kms), 48.1949 Faurei-Tecuci (90kms), 49.1949 Orastie-Cetate (41kms), 50.1949 Telciu-Viseu de Jos (47kms)

*estimate; \#less than 1km; @ not shown on the map

A second major category concerned link lines that either crossed former frontier zones or avoided lengthy detours. Some were relatively straightforward but where the Carpathians had to be crossed they could involve massive engineering work. The first of these projects was a $35 \mathrm{~km}$ line connecting Nadab with Salonta in 1924 (3), completing the main line through western Romania between the Czechoslovak and Yugoslav frontiers: a link of great strategic importance following up the Treaty of Trianon which awarded Romania territory as far west as the edge of the Pannonian Plain. It also provided the most direct connection between three states that were to formalise their mutual defence interests through the Little Entente. Then in 1931 the $44 \mathrm{~km}$ line from Revaca to Cainari (9) in Bessarabia re- duced the distance between Chisinau (the provincial capital) and Galati by avoiding a long detour through Tighina. This was part of an ambitious programme started by the Liberal government in 1924 and involved some reordering of priorities away from a direct link between Chisinau and Balti officially advocated in 1920, no doubt because of the strategic interest in a direct axial route (avoiding the detour through Ungheni) through the province to Cernauti in $\mathrm{Bu}$ covina. Even so the line took seven years to complete (including the $689 \mathrm{~m}$ Tipala tunnel) and depended on the finance arranged externally by the National Peasant government in 1928 and a reconsideration of strategy in the light of the Leverve report in 1929. However the most direct route to Zlati was compromised in order to use the bridge at Cainari on the existing route. An essential accessory to the project was the reconstruction of the bridge over the Prut between Reni and Galati: this was built originally in 1877 but abandoned after the Russo-Turkish War and destroyed by flooding in 1897 before a temporary structure was provided in 1916 and a permanent one in 1928 (it was to be destroyed again during World War Two with reconstruction provisionally and permanently in 1944 and 1947 respectively).

\section{Crossing the Carpathians}

In 1938 a 34km line was opened between Caransebes and Resita (18) to provide a direct link with Bucharest for a metallurgical and engineering centre of the greatest importance for the Romanian economy. But

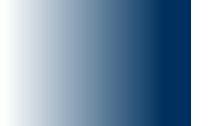


even more significant was the $62 \mathrm{~km}$ line across the Eastern Carpathians connecting Ilva Mica in Transylvania with Vatra Dornei in Bucovina (21). It had been considered by the Habsburg planners in 1898 because there was no railway crossing of the mountains from eastern Transylvania apart from the link from Ciceu to Adjud. When Habsburg forces were cut-off in $\mathrm{Bu}-$ covina by the Brussilow offensive in 1916 it was necessary to build a makeshift tram road from the railhead at Dornisoara to Prundul Bargaului, worked by petrol-elec tric locomotives (150hp petrol engines coupled to a 300v/90w dynamo) and four railcars. After the war the Romanians im mediately opened an office to begin planning the new line and work started in 1924 (along with two other Carpathian projects described below). In the meantime the military tramroad was needed (until 1939) and it was therefore repaired and reopened in 1922. Work continued through out the inter-war period apart from 192934 when the National Peasant government saw a reduced priority for the line in view of the convention signed with Poland in 1928 which provided for trains from Cernauti to Oradea via Sighet and Satu Mare to operate through Polish and Czechoslovak territory, beginning in 1930. However in 1934 strategic considerations returned to the force and the line reached Ilva Mare $(25 \mathrm{kms})$ in 1936. The remaining section was difficult with nine tunnels (total length $2.38 \mathrm{kms}$ ) and the bulk of a total of 191 bridges and viaducts (total length $1.54 \mathrm{kms}$, of which $0.52 \mathrm{kms}$ comprised four large viaducts) The new railway became redundant almost immediately with the loss of North Transylvania in 1940 but it demonstrated its value after the war, although it was necessary to undertake protection work for some $3.16 \mathrm{kms}$ along the Ilva river (with realignment of track at Lesul Ilvei) over a period up to 1953.

1939 saw the opening to Telciu of the first $(15 \mathrm{kms})$ section of a line from Salva to Viseu (23) which was needed to provide a link with Sighet in Maramures (otherwise accessible only via Czechoslovak territory). Until the whole line was open - with a further five tunnels of $3.46 \mathrm{kms}(2.39 \mathrm{kms}$ for the Maramures tunnel alone) a narrow gauge railway opened in 1940 provided a temporary connection with the Borsa branch at Moisei opened in 1940 (25). The line was seen as a low priority after negotiations with Czechoslovakia and Poland en abled trains to run in transit between Cernauti and Oradea from 1930 (in return for facilities for Polish traffic in Bucovina, referred to below). But it became more essen tial under the strategic planning of 1937 and work eventually resumed when Romanian administration returned to northern Transylvania after the war (although transit from Satu Mare through what was now
Soviet territory was allowed from 1947). There was some further thought about the best route, with Baia Mare-Sighet and Iacobeni-Borsa as alternatives (the latter an unlikely option in view of the maximum gradient of $5.2 \%$ encountered by the Hungarian military line built during World War One and the long tunnel that would otherwise be needed), and the project was finished 1949 with a further $47 \mathrm{kms}$ became available (50). 1939 also saw the completion on a line from Larga in Bessarabia crossing the Nistru to reach Kamjanec Podilskyi (22) in the Soviet Union. This is shown in a railway map of the Danubian area (Jordan, 1986) and it may reflect an even-handed approach by Romania towards Germany and the Soviet Union in a bid to protect the country's integrity prior to the territorial losses of 1940. But the project may have originated during World War One in conjunction with Romanian interest in building from Dangeni to Radauti-Prut where a bridge would have given easy access to Lipcani and Larga. Jordan also thinks the line could have been built earlier (between 1924-39) although this would be surprising given the poor relations between Romania and the USSR until 1935. Another possibility is construction by the Soviets after they annexed Bessarabia and North Bucovina in 1940

The nine kilometers of railway opened in 1941 between Bumbesti and Meri in the Jiu defile (27) concerns another of the mountain projects started in 1924 with the aim of reaching the Petrosani coalfield at Livezeni along a highly-challenging route. The aim was to provide a more direct route for the southward flow of coal but to provide an additional link across the old frontier between the Olt valley and the TimisCerna corridor. Work between Targu Jiu and the frontier near Bumbesti was put in hand in 1915-6 and following Romania's defeat in the war the Habsburg administration considered extending the project through the gorges with studies during 1916-8 which the Romanians extended in 1921-4. Romanian governments consistently supported the project (apart from the depression years 1932-6) although it did not always carry top priority. The Meri section included four tunnels with a total length of $0.79 \mathrm{kms}$. It is not clear how much further was done during the war years, but following the partition of Transylvania in 1940, the Hungarians built the $47 \mathrm{~km}$ line between Deda and Saratel (29). Southeastern Transylvania (extending as far south as Sfantu Gheorghe) could not be accessed from Cluj because the main line passed into Romanian territory and hence the need to approach from Satu Mare and head southeastwards through Dej to Gheorgheni and Miercurea Ciuc. The new line, which included two tunnels with a combined length of $1.43 \mathrm{kms}$, was naturally given the highest priority and although it was never a project favoured by Romania it has been of great value since the war in allowing more direct contact between Bucharest and Baia Mare (travelling via Miercurea Ciuc instead of Cluj) and was an early candidate for electrification.

\section{The Oradea-Craiova \\ Strategic Concept}

1944 saw the completion of two sections Brad-Luncoiu (5kms) (35) and Deva-Stoeneasa (15kms) (36) - of the line from Brad to Deva which gave access to an important mining area. Much more important however was the possibility of shortening the distance from Bucharest to Oradea by bridging the gaps Brad-Deva and VascauVarfurile - also Curtea de Arges-Ramnicu Valcea. Along with the latter, Brad-Deva became a priority in the 1941-6 programme after the main line through Transylvania was cut by the Hungarian frontier and the Vascau area was isolated (although the work started in 1939 in connection with an Oradea-Craiova strategic axis which would be achieved through the Bumbesti-Livezeni project). However the work was not finished when the war ended and the return of North Transylvania to Romania removed the major justification to the project which meant that two tunnels $(0.29 \mathrm{kms})$ and 10 viaducts $(1.12 \mathrm{kms})$ remained largely unfinished until work eventually resumed in 1979. Meanwhile completed sections attracted local use in connection with mining and quarrying by the 1960s: limestone working at Craciunesti near Stoeneasa (where the railway included the $301 \mathrm{~m}$ Mures bridge at Mintia) and non-ferrous ores at Dealul Fetii: the latter operation evidently justifying completion of the $217 \mathrm{~m}$ Luncoiu viaduct to extend the line available from Brad by a further two kilometers. Meanwhile however, Meri-Livezeni (20kms) benefited from a 'big push' from 1941 (under a new contract for completion 1945) and continued to enjoy priority with the deployment of 28,000 young workers who finally drove the project to completion in 1948. It is perhaps Romania's most outstanding railway with 35 tunnels (total length: $6.67 \mathrm{kms}$ ) and major buttressing on unstable slopes.

\section{The Projects: \\ New Main Lines}

A third category deals with several lengthy new lines that were substantial projects going beyond the closure of relatively short gaps. To begin with, Dobrogea was seen as being quite inadequately served when strategic issues were raised at the time of the Balkan War (1913) when Romania gained a strip of territory from Bulgaria. A four year development plan for 1913-16 highlighted an axial line across the province from Tulcea in the north to Bazargic in the south, 
crossing the Bucharest-Constanta line at Medgidia. Work started on the southern line in 1912 and reached Bazargic in 1915; whereupon work switched to the Tulcea line (first proposed in 1897 and then planned to start from Dorobantu 1909 before a base at Medgidia was preferred in 1911). However the line reached only to Hamangia (otherwise known as Baia Dobrogea or Targusor) in 1916 when the German occupation prevented further progress. However the line advanced a further $22 \mathrm{kms}$ to Babadag in 1925 (4) and work stopped there for more than ten years (despite continuing priority following the foreign loan and the Leverve Report in 1929) before a new effort in 1935 saw the remaining $39 \mathrm{kms}$ completed 1938 (17) with the major economy of a steeper ruling gradient ( $1.6 \%$ instead of 1.3 ) enabling the projected Cataloi tunnel to be replaced by winding 'serpentine' down into Tulcea. Meanwhile new lines were being built along the Black Sea coast: from Constanta to Eforie (18kms) in 1927 (6) and a further two kilometers to Techirghiol the following year (7). In 1938 the railway reached Mangalia (26kms from Eforie) (19) - an extension of strategic importance, although it not prevent the loss of South Dobrogea in 1940) and there was also a branch of $11 \mathrm{kms}$ from Constanta northwards to the resort of Mamaia (20). Finally on the northern side of the Danube delta the recapture of Bessarabia in 1941 (as part of the Axis advance into the USSR) was followed by a line of some $65 \mathrm{kms}$ to give rail access to the port of Ismail (26) using work already started by the Russians.

Elsewhere a new line was quickly conceived after 1918 to connect Brasov with Buzau (incorporating the Buzau-Nehoiasu branch) in order to link Transylvania directly with Romanian ports and reduce pressure on the difficult and overloaded route over the Predeal summit. It was one of the three mountain railways started in 1924 and was intended to be a two-track railway with gentle gradients that called for a $4.37 \mathrm{~km}$ tunnel between Telciu and Intorsura Buzaului (the longest tunnel in Romania, by more than a kilometer after Beresti, north of Galati, with $3.33 \mathrm{kms}$ ). However, despite further support following the foreign loan and the Leverve Report of 1929, work halted at Intorsura Buzaului in 1931 with only $31 \mathrm{kms}$ complete (10) (starting from Harman, east of Brasov). Unstable terrain added greatly to the costs and little further work was done since it did not carry the highest priority (despite inclusion in the 1941 programme) with the Campina-Brasov widening now in hand. The only result was a narrow-gauge local line as far as Crasna while the standard gauge section engineered to the highest standards continues to carry only sparse local traffic. Similar disappointment attended the plan of 1941 for a new railway to Constanta extending the line from Ploiesti to Tandarei across the Danube at Harsova (first conceived just before World War One): construction extended for only $16 \mathrm{kms}$ to the edge of the Danube at Lunca (31). But there was a more successful outcome for the concept of a new railway to connect Bucharest with both Moldavia and Oltenia through Urziceni, Faurei and Tecuci to the northeast and Rosiorii de Vede, Caracal and Craiova to the southwest. The Bucharest-Urziceni-Faurei line (138kms) was conceived in the 1890s and then given greater priority at the onset of World War One, with work authorised in 1912 and started eventually in 1916. But there was no substantive progress until the 1941 plan which led to new studies in 1942 and completion of the line in 1943 (32). Bucharest-Craiova (209kms) had similar origins and was competed in 1947 (41). Finally the Faurei-Tecuci section $(90 \mathrm{kms})$ was delayed until 1949 (48) with the complications of the Buzau and Siret river crossings at Faurei and Suraia respectively. In the case of the Buzau there was serious flood damage in 1941 followed by adjustment of the meandering river during 1942-6. But the Siret bridge $(429 \mathrm{~m})$ was particularly challenging and even a temporary bridge held up completion of the line until 1949 with a permanent installation following only in 1960.

\section{The Projects: Local Lines, Realignments and Narrow Gauge Projects}

Fourthly, several local lines were built. In chronological order the first was in 1927 and involved a nine kilometer link in the west of the country: one of three projects in Banat where a dense network of local lines was much compromised by the new frontiers. Although Bazias could be reached by transit through Yugoslavia (agreed in 1925) there were three places were new construction in the area was need. In the first case of Comlosu-Teremia, a Hungarian line had been built in 1910 from Arad to Jimbolia, Kikinda and Nerau but this could not be taken over entirely by Romania because the Jimbolia-Kikinda section lay in Yugoslav territory. The new line eventually made an all-Romanian railway available after Nerau's link with Kikinda had closed in 1920 (5). In 1932 a short line in Bucharest from Obor to Pantelimon (12) reduced pressure on the main Gara de Nord in Bucharest by enabling trains on the Constanta line to enter a new suburban station built in the eastern part of the city (an alternative to a grandiose central station concept which was rejected at this time). Then in 1937 a further adjustment in Banat was made by linking Carpinis with Checea (15) (seven kilometers) in order to give access to a branch line leading to Ionel ( $31 \mathrm{kms}$ in all). A Hungarian line of 1897 connecting Jimbolia with Jasa Tomic was closed to through running in 1925 because it crossed the frontier five times. However a lengthy central portion on Romanian territory was reconnected 12 years later in the way described while two smaller sections in Romanian (Foeni) and Yugoslavian territory, along with other short sections at Jimbolia and Jasa Tomic were all abandoned. In 1939 a $10 \mathrm{~km}$ branch was opened from Ucea to the site of a strategically-important chemical industry site at Ucea de Sus (24). However the munitions factory was never finished because delivery of plant from Germany was prevented by the coup of 1944 and the factory was eventually completed as a peacetime project with the name of Victoria (though retaining the remote site selected on the basis of wartime dispersal to reduce the risk of aerial attack). In 1945 a seven kilometer line went from Golenti near Calafat to the Danube at Poiana Mare (38) and there was further adjustment in Banat with the $31 \mathrm{~km}$ Pecica-Nadlac line (39) which gave an allRomanian route to a village on the frontier previously accessible from a station (just across the frontier) on a cross-country route from Arad to Battonya and Mako. In 1948 the $52 \mathrm{~km}$ line from Ploiesti to Targoviste (46) kept pace with the expansion of oil working in Dambovita county by serving Bucsani, Razvad and Teis. The line was first proposed in 1928 but was given high priority from 1943 (in view of the importance of Romanian oil) with completion expected 1944. Also in 1948 (or later) a branch from I.L.Caragiale gave access through Ditesti (45) with former narrow gauge lines to Moreni and Gura Palangii, of interest for oil and lignite mining respectively. Finally in 1948, following the completion of the main line from Bucharest to Urziceni, a $16 \mathrm{~km}$ branch from Caciulati to Snagov (43) was financed by the railway company and the Bucharest municipality anxious to get people to Snagov Lake which was popular for water sports. The study included provision for loop around lake to join the Bucharest-Ploiesti line at Peris but this line was never built (although it could have provided a short cut between the two main lines avoiding Bucharest).

A fifth category covers a number of localised realignments. As part of an agreement with Poland a border crossing was opened at the Schit-Zaleszczyki (8) by rebuilding a bridge originally constructed in 1897 but destroyed during 1919-20. The following year another connection was opened at Vijnita-Kuty over a distance of five kilometers (11) to allow timber trains to transit Romania and re-enter Poland at Grigore Ghica Voda/Sniatyn. Then in 1935 a resumption of transport links with the USSR led to the rebuilding of the border bridge over the Nistru between Tighina and Tiraspol, first built during 1870-4 but destroyed in 1919 (14). Then the dou- 
bling of tracks between Campina and Brasov by 1941 led to some realignment, including the abandonment a tunnel at Busteni (120m) and two at Posada (195m) (28). In 1943 a $16 \mathrm{~km}$ diversion was opened on the Brasov-Sibiu line between Valea Homorod and Sercaia, including the Dealul Negru tunnel (472m) (33). The improvement was needed when Brasov-Sibiu-Copsa MicaAlba Iulia-Arad became a route of first importance after 1940 and the restrictions arising in the Homorod-Sinca area on account of gradient and curvature - as well as the dimensions of the $535 \mathrm{~m}$ Diana tun nel and two reinforced concrete viaducts at Sinca (the first such structures to be built on present Romanian territory). This was the only one of three such improvements envisaged under the 1941-6 plans (the oth-

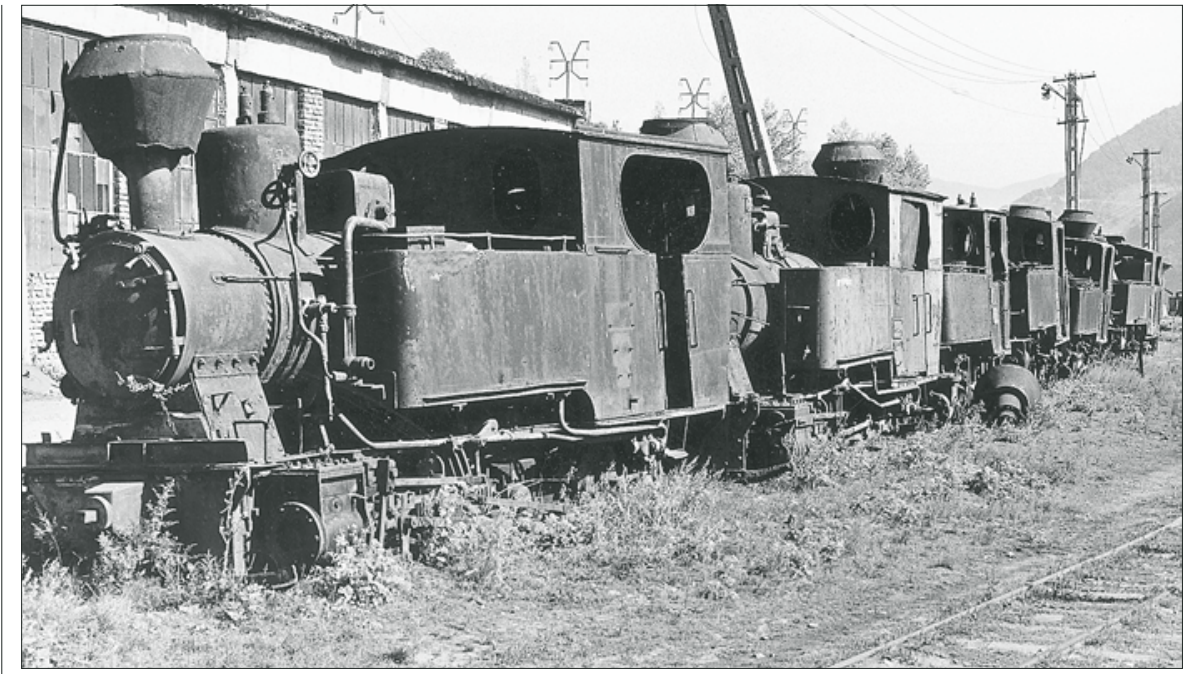

Plate 6. Abandoned locomotives on the Brezasca forest railway system ers were Ocna Sibiului-Miercurea Sibiului between Sibiu and Copsa Mica and Balota at the eastern approach to Turnu Severin).

In 1944 the retreating Germans blew up two tunnels at Boj on the southern approach to Cluj. Although the tunnels were not reopened until 1948 a Russian unit was able to reopen the line in two weeks by constructing a three-kilometer deviation railway for temporary use (34). There was also a $1.1 \mathrm{~km}$ realignment for a new $294 \mathrm{~m}$ Stana tunnel under the Cris-Somes watershed on the Cluj-Oradea line after wartime destruction realignment 1945 - after destruction in the war: a temporary route was constructed above the old tunnel before a new bore was completed in 1947 (40) (and subsequently duplicated when widening occurred in 1976). This section does not take account of bridge reconstructions that involved minor changes in alignment e.g. when $\mathrm{Ca}$ racau viaduct between Ciceu and Ghimes was replaced in wood (1944-5) and then in concrete (1946) - very soon after previous destruction in 1916 had been followed by provisional repairs in 1917 and full recon-

struction in 1944. The Prut bridge at Falciu was also destroyed during World War Two and was rebuilt on a modified alignment in 1943 before further destruction in 1944 and a return to the original alignment after another reconstruction in 1951.

The final category concerns a number of narrow-gauge $(76 \mathrm{~cm})$ lines which do not include those built by the forestry authorities and timber companies at Berzasca and elsewhere (Plate 6). A local railway of some 40kms was opened in 1934 by the Closani company to connect Apa Neagra (near Baia de Arama) with Turnu Severin (13), although landsliding on the escarpment 150-300m above the Danube at ColibasiMalovatu led to closure and a new link with Targu Jiu by 1955 (Plate 7). During 1936-7 the Crasna-Husi narrow gauge (34kms) (16) was converted to standard gauge, presumably for strategic reasons and in 1940 (as already noted) a line of some $20 \mathrm{kms}$ from Telciu to Moisei gave access to Maramures pending completion of the Salva-Viseu project. In 1941 the Hungarians connected Lechinta with Iuda (16kms) (30) as part

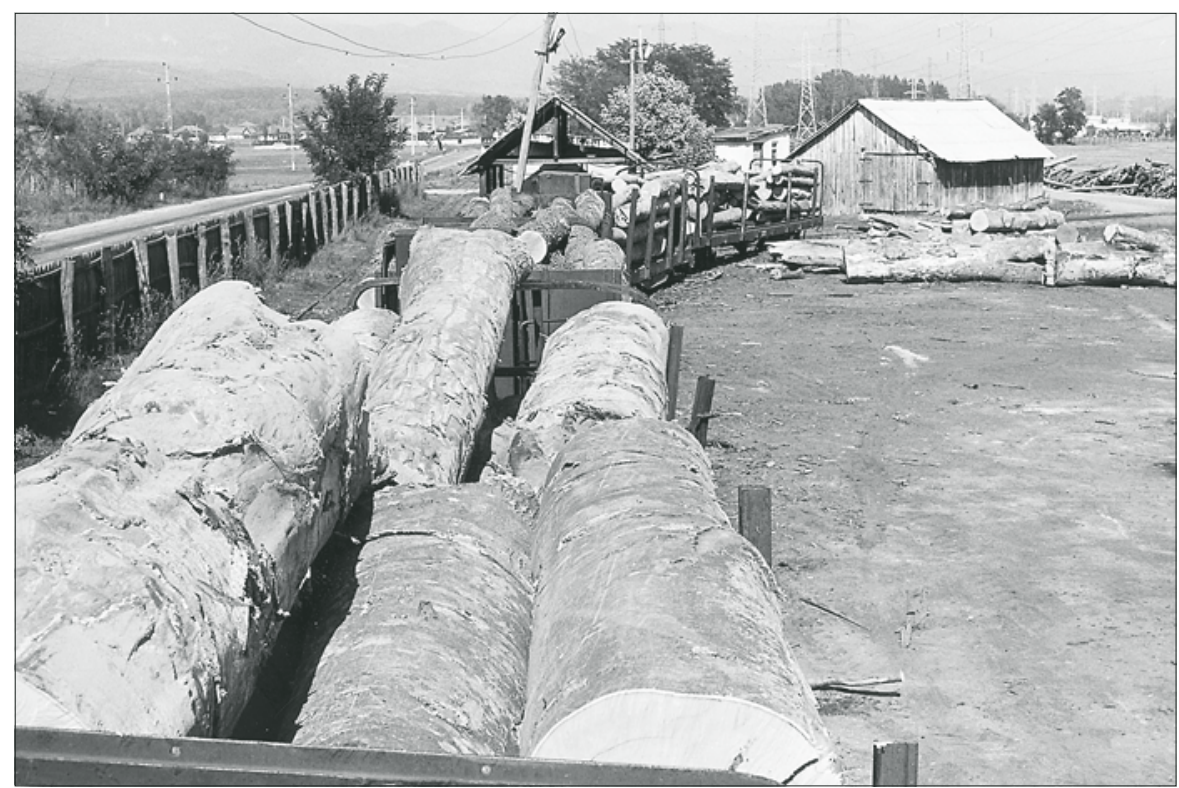

Plate 7. A woodyard near Tismana opened up by the narrow-gauge railway from Apa Neagra to Turnu Severin and its subsequent extensions of the rationalisation of railways in North Transylvania. In 1945 a short new line of some five kilometers was reported between Filipestii de Padure and the Palanga lignite mine (37) where a large thermal power station (sufficient for national electrification along with hydropower from Bicaz and the Iron Gates) seemed a possibility. although such hopes were disappointed. However the line which was built as a ramification of an existing narrow gauge railway from Floresti to Ditesti and Moreni (completed by the Germans during their occupation of 1916-8) and the system was converted to standard gauge in 1948 or later (44) (and the Floresti link broken) following the connection of Ditesti with I.L.Caragiale (on the new Ploiesti-Targoviste railway mentioned above). Reference should be made to the local line of some $20 \mathrm{kms}$ from Intorsura Buzaului to Crasna (1947) (42) which was intended to assist in the extension of the main line project. But the latter was abandoned early in the communist era and the narrow gauge line was handed over to the forestry authorities and extended along tributary valleys to assist the logging industry. Finally another line (of $41 \mathrm{kms}$ ) was built during 1944-9 (49) for local traffic between Orastie to Cetate and this also became a forest railway.

\section{Completing the Network}

The projects reviewed represent a small part of what was considered during the period, inevitably since resources were limited and many of the recommendations were put forward as alternatives. However it worth reviewing the other ideas: they did not comprise any official plan but rather a set of ideals embraced by a number of visionaries. They are shown in Figure 2 which also summarises the construction to 1918 , the new lines subsequently built and the forest railways: with discrimination in the latter case between those lines still operating in the 1970s and those already closed. The map also shows the directness of railway links between Bucharest and other 
towns with the 1918 rail distance calculated as a multiple of the straight line distance (relatively high values of over 1.5 - and especially over 2.0 - point to the need for improved services).

The various recommendations had regional significance in the case of Transylvania where direct lines from Sighisoara to Targu Mures (Danes-Sanpaul) and from Ludus to Turda and Cluj would also shorten the distance to Oradea and improve links with other cities as well. In Wallachia links with the river ports could be improved through railways from Leu near Craiova to Bechet, from Zarnesti to Campulung (for Turnu Magurele) and from Sinaia to Pietrosita (for Giurgiu), with the latter included in the 1913 programme but never implemented. In Moldavia improvements north of Iasi could provide direct access to Botosani via Harlau and with Hotin in Bessarabia via Dangeni, Radauti-Prut and Lipcani or via Dorohoi, Herta and Noua Sulita. Bucovina could also become more accessible with new construction between Veresti and Siret which would avoid Suceava and Dornesti. And with the Ilva Mica-Vatra Dornei line open and the local railways west of Suceava were exposed to main line traffic the bottlenecks at Mestecanis tunnel (on a $2.0 \%$ gradient) and the steep incline of $2.5 \%$ at Strigoaia near Cacica required urgent attention.

Four peripheral areas of the country posed particular concern: Anina and Bazias (the latter accessible only through Yugoslavia) could be reached more easily through a railway starting at Iablanita or Mehadia (north of Orsova) and heading for Oravita (considered by the Hungarians and reportedly implemented momentarily before the First World War). For this reason the Iablanita-Racajdia project via Nera Velley was revived by the Baiulescu plan 1919-20 and reconsidered again in 1934: the distance would have been $102 \mathrm{kms}$ with $2.66 \mathrm{kms}$ of bridges and $4.80 \mathrm{kms}$ of tunnels. Bessarabia needed the Balti-Chisinau-Zlati link (partially realised) and branches to Hotin and Soroca; while the isolation of Dobrogea and Maramures was relieved by projects already described. But there was also a strategic interest in the southern approaches to the Carpathians to allow for speedy despatch of reinforcements to guard passes in the event of an invasion of Transylvania. Hence the proposal for a continuous railway along the southern edge of the mountains continuing the new construction already proposed for Curtea de ArgesRamnicu Valcea to Polovragi, Targu Jiu, Baia de Arama and Baile Herculane on the main line from Turnu Severin and Orsova to Timisoara. The new line would link with the Targu Jiu branch running north from Filiasi and a further link was proposed from Bals to Polovragi. This is an appropriate point to refer to the Curtea de Arges-
Ramnicu Valcea project that was recommended on several occasions as a means of reducing pressure at Predeal while simultaneously reducing the distance from Bucharest to Arad from $599 \mathrm{kms}$ via Brasov (for $590 \mathrm{kms}$ via Turnu Severin) to $544 \mathrm{kms}$. The line was considered in the 1890s and then identified in the 1920s by Baiulescu, Cottes$\mathrm{cu}$ and Petculescu as well as by Tudoran in 1934. Extensive studies were carried out in 1931-2 and in 1942 when the project complemented the Oradea-Craiova concept. But there is no evidence of any construc tion despite further studies in 1948-9 and the saga therefore extended into the communist era (Peaha, 1965). Decision-making was not helped by major construction problems and alternative routes based on Bascov near Pitesti, Valcele further north or Curtea de Arges. The Valcele route involved two tunnels of $4.16 \mathrm{kms}$ along with bridges over the Arges and Olt, plus ten major viaducts (total length $3.25 \mathrm{kms}$ ).

\section{The International Dimension}

Much thought given to international connections as the number of through coaches to destinations abroad increased from eight daily in 1914 to 33 in 1926 (including with Wagon Lits coaches to Amsterdam, Berlin, Budapest, Calais, Linz, Ostend, Paris and Prague/Karlovy Vary, Vienna and Warsaw). Most international services crossed the frontier just beyond Arad or Cernauti where the relevant stations (Curtici and Napolacauti) were rebuilt and renamed Decebal and Grigore Ghica Voda respectively. But better connections were needed to Romania's Little Entente partners. For Czechoslovakia the improved domestic arrangements with Maramures would provide access over the frontier at Campulung pe Tisa near Sighet but shortening the route from Bucharest to Belgrade via Timisoara would require either a long cross-country line from Iablanita or Mehadia (north of Orsova) along the Nera valley to meet he Oravita-Bazias line at Racajdia; or a bridge over the Danube between Turnu Sever in and Calafat (Gruia or Tiganasi) to meet the Serbian narrow gauge in the Timok valley: also a potentially useful route to Greece and southern Yugoslavia (Petcules$\mathrm{cu}, 1943)$. However the bridge would have been hugely expensive while the Iablanita-Racajdia line would also have been difficult - and entirely a Romanian concern - although it would have helped to meet a strategic concern over access to southern Banat already discussed.

Other ideas of international interest included an east-west axial route across Eastern Europe that would use the existing Oradea-Cluj line (with additional branch es to lead in traffic from Beius, Simleu Silvaniei and Zalau) and then strike a new course eastwards to Reghin, Ditrau, Tulghes, Targu Neamt and Pascani where exist- ing lines would lead on to Iasi and Chisinau. New construction could be reduced by using the lines already available in Transylvania between Reghin and Toplita or by shifting the route further to the north to the Ilva Mica-Vatra Dornei route (under construction) and an additional new line from Gura Humorului to Roman. There was also an interest in the ports of the Black Sea and Lower Danube with both domestic and international traffic in mind. One important supply line could reach Ismail by way of Cernauti, Lipcani, Ocnita, Balti, Orhei, Chisinau, Basarabeasca and Bolgrad; requiring a more direct line between Balti to Chisinau (as well as the Revaca-Cainari line opened in 1931) and a link between Bolgrad and Ismail (as an alternative to the route through Arciz that was eventually preferred). From Ismail some visionaries conceived of a railway crossing the Danube to reach Tulcea and Constanta. A further option was a new port at Jibrieni on the Bessarabian coast immediately east of the Danube delta; requiring a branch from $\mathrm{Ba}$ sarabeasca to handle traffic that might arrive in the area by means of the 'central railway' from Budapest via Cluj, Iasi and Chisinau.

Another route would connect Sighet with Piatra Neamt via Borsa, Iacobeni and Vatra Dornei and then use existing lines to Galati through Bacau, Marasesti and Tecuci; with possible extensions to Ismail via Foltesti and Cahul; and to Isaccea, Tulcea and Sulina by means of a bridge or train ferry across the Danube at Galati. Galati could also be reached from southern Transylvania by new lines from Odorhei to Ciceu or from Bretcu to Onesti - both feeding on to the existing main line to Adjud with Bessarabian ports then accessible by new construction from Adjud to Nichiseni leading on to Birlad, Falciu and Basarabeasca. Yet another approach lay through the Harman-Buzau and Tandarei-HarsovaConstanta projects where implementation was attempted. Finally Bucharest's links with Dobrogea could be improved by the extension of the Oltenita branch across the Danube (or by a tunnel under the river) to reach Turtucaia, Silistra, Arman and Balcic (the latter also to be connected with Mangalia and Constanta). In a class of its own was Tudoran's speculation of 1943 concerning Hitler's idea of a broad gauge railway system embracing Eurasia: this might have placed Bucharest at the intersection of routes connecting Hamburg with Saigon and Helsinki with Central Africa!

\section{Conclusion}

The period covered by this paper was a critical one for the railway network when there was many inherited deficiencies to be addressed. In contrast to grandiose visionary schemes, specific plans were always relatively modest in scope but were to a considerable 
extent realised, sometimes after considerable delay which may be attributed to capital shortage, wartime pressures, changing international circumstances and, above all, the engineering difficulties in dealing with mountainous and unstable terrain. Furthermore, the interest in new projects had to be balanced against the need to modernise the existing network. Given the limited resources and a measure of conflict between economic and strategic objectives, the progress was substantial and many of the defects in the inherited network in terms of indirect routes from Bucharest to some large population centres were satisfactorily addressed. Four decades of communist central planning brought little further expansion of the network except in new coalmining areas and the emphasis placed on widening and electrification points to the rationality of earlier decision making. However, the network still shows many signs of its origins in a territo- rial context very different from that of the present

\section{Bibliography}

Iordanescu, D. Georgescu, C. (1986): Constructii pentru transporturi in Romania (Bucharest: Centrala de Constructii Cai Ferate).

Jordan, P. (1986): 'Transport': Breu, J. ed., Atlas of the Danubian countries (Vienna: Franz Deuticke Verlags/Universitatsbuchhandlung) 353.

Peaha, M. (1965): 'Contributii la studiul posibilitatilor de construire caii ferate Curtea de Arges-Rimnicu Vilcea', Comunicare de Geografie 3, 287-300.

Petculescu, N.I. (1923): Problema CFR: istorie completari imbunatatiri (Bucharest: Cultura Nationala).

Petculescu, N.I. (1943): 'Marea cale de comunicatie a Romaniei cu Peninsula Balcanica', Revista CFR 29, 141-6.
Serbanescu, D. (1936): 'Electrificarea liniilor CFR', Revista CFR 23, 136-47.

Tudoran, M. (1934), Orientarea sistematizarea si completarea retelei CFR (Bucharest: $(F R)$.

Tudoran, M. (1941): 'Constructiile de linii noi ferate in legatura cu programul de investitii CFR', Buletinul Societatii Politechnice din Romania 40, 767-93.

Tudoran. M. (1943) 'Idei noi in constructie drumurilor de fier', Revista CFR 29, 179-89.

Turnock, D. (1979), 'The Romanian railway debate: a theme in political geography', Journal of Transport History 5, 105-21.

Turnock, D. (1987), The development of the Romanian railway network since the First World War (Leicester: Leicester University Geography Department Occasional Paper 16). 